\title{
Influence of Long Term Application of Green Manure on the Productivity of Coconut Cultivated in Reddish Brown Latosolic Soils in Sri Lanka
}

\author{
S.H.S. Senarathne
}

\begin{abstract}
Organic matter contributes in maintaining soil fertility in agriculture. Green leaf biomasses of Gliricidia sepium and Tithonia diversifolia are high in plant nutrients and recognized as potential green manure sources for many crops. In a field experiment carried out in a coconut plantation with Reddish Brown Latosolic soil, two green manure crops were grown to study their abilities and establishment in coconut avenues and to evaluate their effect on nut yield. In situ green manuring, especially with legumes, had the most beneficial effect on soil improvement. The use of green biomass alone has improved soil properties. The biomasses of Gliricidia and Tithonia decomposed rapidly after application to the soil, and incorporated biomass would be an effective source of $\mathrm{N}, \mathrm{P}$ and $\mathrm{K}$ for crops. Results showed that, coconut yields were significantly increased with the incorporation of green biomass of Gliricidia and Tithonia than with commercial inorganic fertilizer application. Mean nut yield for five years in the green manure applied plots was $(37-46 \%)$ significantly $(\mathrm{P}<0.05)$ higher, compared to that of the inorganic fertilizer applied plots towards the latter part of the experiment. Addition of green manure has significantly $(\mathrm{P}<0.05)$ improved the soil parameters i.e. soil $\mathrm{N}$ (by $75 \%$ ), organic $\mathrm{C}$ content (by $86 \%$ ) and soil microbial activity (by $52 \%$ ). Soil bulk density has been reduced by $20 \%$ which enhances the root growth. The improvement of soil moisture content by $92 \%$ is of great importance for coconut in withstanding the frequent dry spells which are on increasing trend with the present climatic change situations. There was no significant effect of green manures on soil $\mathrm{pH}$ and $\mathrm{P}$ but $\mathrm{P}$ content was improved with the use of green biomasses of Gliricidia and Tithonia.
\end{abstract}

Key words: Gliricidia, Coconut, Tithonia, green manure, soil amendment

Running title: Influence of green manures on coconut land productivity

\section{Introduction}

Crop productivity in coconut farming system is achieved by a combination of management strategies, among which the development of an efficient and effective nutrient recycle plays an important role. This is due to the large-scale export of nutrients through produce and stubble, which in conventional systems is replaced by chemical fertilizers. In contrast, exsitu or in situ green manures, animal manure, cover crops or different types of organic matter are used individually or in combination to replenish exported nutrients in organic systems (Stokdale et al., 2000). In the tropics, where soil fertility is generally low (Hartemink, 2003; Zingore et al., 2003), the decline in crop yields, even in conventional cropping systems due to excess soil mining calls for the inclusion of organic matter to maintain soil fertility (Gachengo et al., 1999; Eilitta et al., 2004). Nutrient replenishment and quality enhancement of tropical soils could be achieved by the addition of inorganic-fertilizers, organic

Agronomy Division, Coconut Research Institute, Lunuwila, Sri Lanka.

Email: shsumith71@yahoo.com 
matter or both. While short-term benefits could be gained by inorganic fertilizers, harmful effects could develop in the long term (Nosengo, 2003). Green manures are the ideal method of sustaining soil fertility in the tropics (Joergensen, 2002; Fageria, 2007), for both soil fertility and microbial activity (Palm et al., 2001). The organic matter status of the soil can be maintained by the addition of green leaves, compost or farm yard manure. However, in many coconut plantations, growers are unable to apply the required quantities of compost or farm yard manure because of inadequately supply. Different types of organic materials can be added to the soil to improve the soil conditions (Nagarajah and Amarasiri, 1977). Plant species for use in biomass transfer must accumulate large amounts of nutrients in their biomass, and these nutrients must be readily released in plant available forms when the biomass is applied to crop growing areas (George et al., 2001). Hence, cultivation of green manure crops in situ and their incorporation were considered to be a viable alternative. This is practiced by the farmer as it is the most convenient and economic method of enhancing the organic matter status of the soil. Tithonia diversifolia (Hemsley) A. Gray has been identified as a useful resource for biomass transfer (Niang et al., 1996; Gachengo et al., 1999). It has been used successfully to improve soil fertility and crop yields in Kenya (Jama et al., 2000), Malawi (Ganunga et al., 1998), Nigeria (Ayeni et al., 1997).It is a common plant abundantly in upcountry areas of Sri Lanka. Concentration of nitrogen (N), phosphorus $(\mathrm{P})$ and potassium $(\mathrm{K})$ in its green leaf biomass are relatively high (Jama et al., 2000). Leguminous green manure crops can be used to improve the soil structure and nitrogen status of the soil. The most common green biomass source in coconut plantations has been Gliricidia sepium due to its abundance. It's a fast growing tropical legume tree and leaf manuring improves physical, chemical and biological properties of the soil (Sangakkara, 1989). Gliricidia is widely used as green manure in different cropping systems and is reported as a substitute for synthetic nitrogen fertilizers (Okogun et al., 2000; Chirwa, 2006). However, the suitable types of materials to be added to the soil and their long-term effects in increasing the productivity are not known with certainty in Sri Lanka.

Some areas of the intermediate zone of Sri Lanka are characterized by the presence of Reddish Brown Latasolic soils. Since soil fertility of this soil group is comparatively much lower to its counterpart the Reddish Brown Earth (Rhodudalfs), the need for either improving or at least maintaining the organic matter status was identified as prime importance of the great soil group. However, the impact of green biomass applied as mulch or incorporated on soil development and productivity of coconut palms in Reddish Brown Latasol soils has not been clearly identified especially in field studies on coconut farming systems. The objectives of this study were to monitor the long term effects in coconut land productivity due to the addition of different green biomass materials and the inorganic fertilizer in coconut plantations in Reddish Brown Latasol soils in this region.

\section{Materials and methods}

This experiment was carried out at the Ridigama Estate, Dodangaslanda, in the Low country Intermediate Zone of North Western Province of Sri Lanka from January 2007 to December 2012. The area is characterized by bimodal pattern of rain fall with an annual mean precipitation of $1500 \mathrm{~mm}$. Approximately 65\% of the annual rainfall is received from September to February (Maha). There is a smaller peak of rainfall from March to May (Yala), but the rainfall is erratic. Higher ambient air and soil temperatures (about $28^{\circ} \mathrm{C}-32^{\circ} \mathrm{C}$ ) and bright sunshine hours (about $6-8$ hours per day) are more common especially during the dry periods from May to September. The soil at the site is a Reddish Brown Latasolic (RBL) (USDA soil taxonomy - Rhodudalfs fine loamy, noncalcareous, isohyperthermic), (FAO/UNESCO soil taxonomy - RhodicCutanicLuvisols) soil. Soils are very deep and well drained. Surface soil is dark brown in colour with a sandy clay loam texture. The sub surface soil is dark reddish brown to dark red in colour and texture ranges from clay loam to clay. Structure of the sub surface soil is moderately developed coarse sub 
angular blocky with patchy cutans on ped faces. However, during the dry season ground water table remains at $10-12 \mathrm{~m}$ below the ground surface. Reaction of the soil is slightly acidic (pH 6.0 - 6.5) throughout the soil profile (Mapa et al., 2005).

Age of the coconut plantations was 50 years and trees were planted at a spacing of $8 \mathrm{mx}$ $8 \mathrm{~m}$ (giving a density of 137 trees/ha). Fifteen centimeter long well matured Tithonia stem cuttings and 3.5 feet long well matured Gliricidia sticks were used for planting the trials. The cuttings of both species were established separately as treatments with rains in 2007. Double rows of Tithonia and Gliricidia cuttings were planted in between two rows of coconut palms, at a spacing of $1 \mathrm{~m} \times 2 \mathrm{~m}$ (2250 cuttings $\left.\mathrm{ha}^{-1}\right)$. The distance between coconut palms and green biomass species (Tithonia and Gliricidia) was $3 \mathrm{~m}$. Each experimental plot was $384 \mathrm{~m}^{2}$ (consisting six coconut squares) in size and plots were separated by a single row of coconut. Experimental treatments were arranged in a Randomized Block Design with three replicates. Both green manure species were left to grow during the first 18 months without pruning. The first pruning was done on May 2009 in both treatments. In Tithonia treatment, all the plants initially were cut back to the designated cutting height of $0.6 \mathrm{~m}$. At each subsequent cutting, all coppice sprouts on the Tithonia stumps were cut back to within $1 \mathrm{~cm}$ of the stump. Gliricidia treatment, all the coppice sprouts were cut back to within $4 \mathrm{~cm}$ of the stump. Both species were cut two times per year with onset of monsoon rains. Pruned green biomass was thatched around the coconut palms $2.5 \mathrm{~m}$ radius within each treatment plots. This management allowed the establishment of a vigorous stand of Gliricidia and Tithonia.

Before starting the experiment, all the coconut palms were applied with $3 \mathrm{~kg}$ of adult palm fertilizer mixture (800g Urea, 600g Rock Phosphate and $1600 \mathrm{~g}$ Muriate of Potash) with $1000 \mathrm{~g}$ of Dolomite/palm/ year. However, in control treatment palms were regularly fertilized with adults palm mixture. Coconut palms in $\mathrm{T}_{1}$ and $\mathrm{T}_{2}$ treatments, $50 \mathrm{~kg}$ of Gliricidia and $35 \mathrm{~kg}$ of Tithonia green biomass were applied respectively. (The quantity biomass application was determined by the nutrient contents of the green biomass species). Green biomass applied palms were fertilized with $50 \%$ of the fertilizer mixture.

\section{Soil Sampling and analysis}

From the commencement of the experiment, Soil samples were randomly collected $2.5 \mathrm{~m}$ away from the effective root zone of the coconut palms at $0-30 \mathrm{~cm}$ depth for determination of available and exchangeable plant nutrients in the soil. Simultaneously, an undisturbed soil sample was collected using a core-sampler at depths of $0-15 \mathrm{~cm}$ and $15-30 \mathrm{~cm}$. Samples were processed under laboratory conditions by air drying separately at room temperature for 48-72 hours without any contaminations. Air dried soil samples were crushed and sieved through $2 \mathrm{~mm}$ sieve. In addition, undisturbed soil samples were collected from same locations to determine microbial activity.

\section{Soil moisture content}

Soil samples were collected from four random points from the $2.5 \mathrm{~m}$ away from the effective coconut palms a depth $0.3 \mathrm{~m}$, to determine treatment effects on soil moisture content during dry period following IAEA (2008) gravimetric method.

\section{Data analysis}

Experimental data were analysed following Analysis of Variance (ANOVA) procedure using the statistical software SAS (SAS reference) and the significance of the differences between means was tested using Least Significant Differences (LSD) at $\mathrm{P}=0.05$ (SAS Institute 1999).

\section{Results and Discussion}

Effect of green manuring on soil physical properties (soil moisture and bulk density)

During the experimental period, soil moisture content was measured and it was significantly changed $(\mathrm{P}<0.05)$ during the last two years of the experimental period (Table 1). However, green manuring treatments have 
Table 1. Effect of different green manures on soil moisture content (\%)

\begin{tabular}{|l|c|c|c|c|c|}
\hline \multicolumn{1}{|c|}{ Treatments } & \multicolumn{5}{|c|}{ Soil moistures content (\%) } \\
\cline { 2 - 6 } & $\mathbf{2 0 0 8}$ & $\mathbf{2 0 0 9}$ & $\mathbf{2 0 1 0}$ & $\mathbf{2 0 1 1}$ & $\mathbf{2 0 1 2}$ \\
\hline $\mathrm{T}_{1}$ - Gliricidia green manure & 2.76 & 3.62 & 1.44 & 4.56 & 2.98 \\
$\mathrm{~T}_{2}$ - Tithonia green manure & 2.85 & 3.53 & 1.47 & 4.28 & 3.04 \\
$\mathrm{~T}_{3}$ - Control (APM) & 3.15 & 3.13 & 1.27 & 2.98 & 1.58 \\
Significance & $\mathrm{ns}$ & $\mathrm{ns}$ & $\mathrm{ns}$ & $*$ & $*$ \\
LSD $(\mathrm{P}<0.05)$ & - & - & - & 0.403 & 0.307 \\
\hline
\end{tabular}

* Significantly different at $\mathrm{P}=0.05$; NS- not significant

Table 2. Effect of different green manures on soil bulk density $(\mathrm{g} / \mathrm{cm} 3)$

\begin{tabular}{|l|c|c|c|c|c|}
\hline \multicolumn{1}{|c|}{ Treatments } & \multicolumn{5}{|c|}{ Soil bulk density $(\mathbf{g} / \mathbf{c m 3})$} \\
\cline { 2 - 6 } & $\mathbf{2 0 0 8}$ & $\mathbf{2 0 0 9}$ & $\mathbf{2 0 1 0}$ & $\mathbf{2 0 1 1}$ & $\mathbf{2 0 1 2}$ \\
\hline $\mathrm{T}_{1}$ - Gliricidia green manure & 1.63 & 1.58 & 1.49 & 1.42 & 1.36 \\
$\mathrm{~T}_{2}$ - Tithonia green manure & 1.68 & 1.58 & 1.47 & 1.45 & 1.46 \\
$\mathrm{~T}_{3}$ - Control (APM) & 1.71 & 1.64 & 1.68 & 1.73 & 1.69 \\
Significance & $\mathrm{ns}$ & $\mathrm{ns}$ & $*$ & $*$ & $*$ \\
LSD $(\mathrm{P}<0.05)$ & - & - & 0.18 & 0.19 & 0.18 \\
\hline
\end{tabular}

* Significantly different at $\mathrm{P}=0.05$; NS- not significant

Table 3. Effect of different green manures on soil microbial activity (mg/day)

\begin{tabular}{|l|c|c|c|c|c|}
\hline \multirow{2}{*}{ Treatments } & \multicolumn{5}{|c|}{ Microbial activity (mg/day) } \\
\cline { 2 - 6 } & $\mathbf{2 0 0 8}$ & $\mathbf{2 0 0 9}$ & $\mathbf{2 0 1 0}$ & $\mathbf{2 0 1 1}$ & $\mathbf{2 0 1 2}$ \\
\hline $\mathrm{T}_{1}$ - Gliricidia green manure & 77.5 & 91.9 & 109.8 & 116.2 & 116.4 \\
$\mathrm{~T}_{2}$ - Tithonia green manure & 71.9 & 86.2 & 113.9 & 111.4 & 119.8 \\
$\mathrm{~T}_{3}$ - Control (APM) & 71.5 & 74.7 & 68.3 & 84.5 & 76.4 \\
Significance & $\mathrm{ns}$ & $\mathrm{ns}$ & $*$ & $*$ & $*$ \\
LSD $(\mathrm{P}<0.05)$ & - & - & 23.2 & 12.8 & 22.3 \\
\hline
\end{tabular}

* Significantly different at $\mathrm{P}=0.05$; NS- not significant

Table 4. Effect of different green manures on soil pH

\begin{tabular}{|l|c|c|c|c|c|}
\hline \multicolumn{1}{|c|}{ Treatments } & \multicolumn{5}{c|}{ Soil pH } \\
\cline { 2 - 6 } & $\mathbf{2 0 0 8}$ & $\mathbf{2 0 0 9}$ & $\mathbf{2 0 1 0}$ & $\mathbf{2 0 1 1}$ & $\mathbf{2 0 1 2}$ \\
\hline $\mathrm{T}_{1}$ - Gliricidia green manure & 5.42 & 5.73 & 5.56 & 5.37 & 5.59 \\
$\mathrm{~T}_{2}$ - Tithonia green manure & 5.58 & 5.68 & 5.68 & 5.28 & 5.43 \\
$\mathrm{~T}_{3}$ - Control (APM) & 5.41 & 5.71 & 5.70 & 5.91 & 5.65 \\
Significance & $\mathrm{ns}$ & $\mathrm{ns}$ & $\mathrm{ns}$ & $\mathrm{ns}$ & $\mathrm{ns}$ \\
LSD $(\mathrm{P}<0.05)$ & - & - & - & - & - \\
\hline
\end{tabular}

* Significantly different at $\mathrm{P}=0.05$; NS- not significant

Table 5. Effect of different green manures on soil available $\mathbf{P}(\mathrm{ppm})$ content

\begin{tabular}{|l|c|c|c|c|c|}
\hline \multicolumn{1}{|c|}{ Treatments } & \multicolumn{5}{c|}{ Soil P (ppm) } \\
\cline { 2 - 6 } & $\mathbf{2 0 0 8}$ & $\mathbf{2 0 0 9}$ & $\mathbf{2 0 1 0}$ & $\mathbf{2 0 1 1}$ & $\mathbf{2 0 1 2}$ \\
\hline $\mathrm{T}_{1}$ - Gliricidia green manure & 11.32 & 12.41 & 13.42 & 14.94 & 15.34 \\
$\mathrm{~T}_{2}$ - Tithonia green manure & 12.50 & 14.61 & 14.30 & 13.26 & 13.38 \\
$\mathrm{~T}_{3}$ - Control (APM) & 11.45 & 10.98 & 11.48 & 12.85 & 12.01 \\
Significance & $\mathrm{ns}$ & $\mathrm{ns}$ & $\mathrm{ns}$ & $\mathrm{ns}$ & $\mathrm{ns}$ \\
LSD $(\mathrm{P}<0.05)$ & - & - & - & - & - \\
\hline
\end{tabular}

* Significantly different at $\mathrm{P}=0.05$; NS- not significant 
shown a quantitatively higher content of soil moisture compared with the control treatments. Soil moisture content was not significantly changed between green manure treatments $T_{1}$ and $\mathrm{T}_{2}$. In contrary $\mathrm{T}_{2}$ recorded quantitatively higher moisture content in year 2012.

$\mathrm{T}_{1}$ showed higher moisture content in 2011 compared to other treatments. Interestingly, control treatment $\left(\mathrm{T}_{3}\right)$ recorded the lowest moisture content during the whole experimental period. Increased soil moisture content might be due to the application of green manures which might have improved soil physical properties. Further the higher organic carbon content of the soil which resulted in increased water holding capacity of the soil (Ji and Under, 2001). Soil organic matter is responsible to a great extent, directly or indirectly for making the good physical environment of the soil suitable for the growth of plant roots (Jeyamala and Soman, 1999). Application of green manures reduced bulk densities of soil (Table 2), which is a vital soil characteristic for successful root development (Kuchenbuch and Ingram, 2004). There were no significant differences in the bulk densities of soils to which the two green manures were added during the first two years. However, there was a significant effect of treatments on soil bulk density at the end part of the experimental period. The lowest bulk densities were observed in $T_{1}$ and $T_{2}$ during the last three years of the experimental period. A high level of organic matter in the soil indicates reduced bulk density, improved soil structure, aeration and high water holding capacity all of which are attributes of a productive soil (Hseih and Hseih, 1990).

\section{Effect of green manuring on soil biological properties (microbial activity)}

There was a significant effect of treatments on soil microbial activity during the last three years of the experimental period (Table 3 ). The highest soil microbial activities were recorded in green manure applied treatments $\left(T_{1}\right.$ and $\mathrm{T}_{2}$ ) when compared with control treatment $\left(\mathrm{T}_{3}\right)$. The lowest soil microbial activity was observed in control treatment during the whole period of the experiment (Table 3). The application of green manures to the soil is considered as a good management practice because stimulate soil microbial growth and activity with subsequent mineralization of plant nutrients (Eriksen, 2005); and therefore increase soil fertility and quality (Doran et al., 1988).

\section{Effect of green manures on soil chemical properties (soil $\mathrm{pH}$, organic $\mathrm{C}$, available $\mathrm{P}$, total $\mathbf{N}$ and exchangeable $\mathbf{K}$ )}

Green manure applications have no significant impact on soil $\mathrm{pH}$ and soil available phosphorus content during the whole period of the experiment (Tables 4 and 5). However soil available $\mathrm{P}$ content increased with time during the experimental period and the highest value was given by Gliricidia green manuring treatment $\left(\mathrm{T}_{1}\right)$ (Table 5).

In this study, there was a significant effect of green manure treatments on soil $\mathrm{N}$ and $\mathrm{K}$ contents when compared with control treatments during the last three years of the experimental period (Tables 6 and 7). The highest total $\mathrm{N}$ content was given by $\mathrm{T}_{1}$ and $\mathrm{T}_{2}$. Green manures improves the nutrient availability of the soil (Seiter and Horwath, 2004), a phenomenon observed under field conditions of this study (Table, 6). The mean increment in soil $\mathrm{N}$ due to application of green manures (Gliricidia and Tithonia) was $76.7 \%$ and $76.5 \%$ respectively when compared to the sols that did not receive green manures $\left(\mathrm{T}_{3}\right)$. The both green manures increased the total $\mathrm{N}$ content of the soil (Table, 6). Soil nitrogen plays an important role in improving the productivity and sustainability of these farming systems which is also a simultaneous effect of using high quality organic manures (i.e. organic manures with low C: $\mathrm{N}$ ratio) (Six et al., 2002). However, in tropical regions, low availability of soil organic carbon and nitrogen and incorporation of insufficient quantities of organic matter leads to poor-quality soil and low sustainability (Egodawatta et al., 2012). George et al., (2001) also recorded that short fallows of $T$. diversifolia increased total soil $\mathrm{N}$, thus $T$. diversifolia is not $\mathrm{N}_{2}$-fixing, the increase in total $\mathrm{N}$ due to a transfer of $\mathrm{N}$ from deeper soil horizons to the topsoil, or due to fallow-associated non-symbiotic $\mathrm{N}_{2}$ - fixation. 
Table 6. Effect of different green manures on soil total N (ppm) content

\begin{tabular}{|l|c|c|c|c|c|}
\hline \multicolumn{1}{|c|}{ Treatments } & \multicolumn{5}{c|}{ Soil N (ppm) } \\
\cline { 2 - 6 } & $\mathbf{2 0 0 8}$ & $\mathbf{2 0 0 9}$ & $\mathbf{2 0 1 0}$ & $\mathbf{2 0 1 1}$ & $\mathbf{2 0 1 2}$ \\
\hline $\mathrm{T}_{1}$ - Gliricidia green manure & 287.2 & 324.4 & 332.4 & 495.0 & 581.7 \\
$\mathrm{~T}_{2}$ - Tithonia green manure & 301.0 & 315.3 & 346.8 & 510.7 & 580.9 \\
$\mathrm{~T}_{3}$ - Control (APM) & 311.8 & 315.7 & 265.2 & 322.1 & 329.1 \\
Significance & $\mathrm{ns}$ & $\mathrm{ns}$ & $*$ & $*$ & $*$ \\
LSD $(\mathrm{P}<0.05)$ & - & - & 22.7 & 39.7 & 29.4 \\
\hline
\end{tabular}

* Significantly different at $\mathrm{P}=0.05$; NS- not significant

Table 7. Effect of different green manures on soil exchangeable $K(\mathbf{m e q} / \mathbf{1 0 0 g})$

\begin{tabular}{|l|c|c|c|c|c|}
\hline \multirow{2}{*}{ Treatments } & \multicolumn{5}{c|}{ Soil K (meq/100g) } \\
\cline { 2 - 6 } & $\mathbf{2 0 0 8}$ & $\mathbf{2 0 0 9}$ & $\mathbf{2 0 1 0}$ & $\mathbf{2 0 1 1}$ & $\mathbf{2 0 1 2}$ \\
\hline $\mathrm{T}_{1}$ - Gliricidia green manure & 0.068 & 0.082 & 0.108 & 0.116 & 0.296 \\
$\mathrm{~T}_{2}$ - Tithonia green manure & 0.072 & 0.082 & 0.113 & 0.129 & 0.328 \\
$\mathrm{~T}_{3}$ - Control (APM) & 0.061 & 0.077 & 0.091 & 0.087 & 0.102 \\
Significance & $\mathrm{ns}$ & $\mathrm{ns}$ & $*$ & $*$ & $*$ \\
LSD $(\mathrm{P}<0.05)$ & - & - & 0.008 & 0.02 & 0.03 \\
\hline
\end{tabular}

* Significantly different at $\mathrm{P}=0.05$; NS- not significant

Table 8. Effect of different green manures on soil organic $\mathrm{C}$ content (\%)

\begin{tabular}{|l|c|c|c|c|c|}
\hline \multirow{2}{*}{ Treatments } & \multicolumn{5}{c|}{ Soil organic C (\%) } \\
\cline { 2 - 6 } & $\mathbf{2 0 0 8}$ & $\mathbf{2 0 0 9}$ & $\mathbf{2 0 1 0}$ & $\mathbf{2 0 1 1}$ & $\mathbf{2 0 1 2}$ \\
\hline $\mathrm{T}_{1}$ - Gliricidia green manure & 1.08 & 1.18 & 1.38 & 1.78 & 1.98 \\
$\mathrm{~T}_{2}$ - Tithonia green manure & 1.12 & 1.45 & 1.47 & 1.95 & 2.12 \\
$\mathrm{~T}_{3}$ - Control (APM) & 1.04 & 1.12 & 1.09 & 1.11 & 1.06 \\
Significance & $\mathrm{ns}$ & $\mathrm{ns}$ & $\mathrm{ns}$ & $*$ & $*$ \\
LSD $(\mathrm{P}<0.05)$ & - & - & - & 0.58 & 0.84 \\
\hline
\end{tabular}


Generose et al., in 1998 has identified that Tithonia is a high quality organic source in terms of nutrient release and supplying capacity.

The similar phenomenon also observed with soil exchangeable $\mathrm{K}$ content; mean value of soil K were enhanced by $190 \%$ and $221 \%$ when Gliricidia and Tithonia green biomass were applied treatments (Table 7). However, soil K contents were increased by Tithonia which is generally high in these nutrients (Jama et al., 2000). The results clearly highlight the importance of organic materials in improving soil quality and fertility. Incorporation develops greater benefits confirming the reports (Schjonning et al., 2004) under divers' range of ecological conditions. Generose et al., in 1998 has identified that Tithoniais a high quality organic source in terms of nutrient release and supplying capacity. According to the Olabode et al., in 2007 Lower C/N ratio of Tithonia compared to Chromolaena and Panicum indicates a faster rate of decomposition.

The results indicate the green manure application increased soil organic carbon content of manure amended soils. There was a significant effect of treatments on soil organic C content during the last two years of the experimental period (Table 7). The highest soil organic $\mathrm{C}$ content was recorded in green manure applied treatments $\left(\mathrm{T}_{1}\right.$ and $\left.\mathrm{T}_{2}\right)$ when compared with control treatment $\left(\mathrm{T}_{3}\right)$. Similar results was observes by Follett et al., (2007). From several studies it has been found that the addition of organic residues increases the soil organic carbon level initially and with the course of time organic carbon content decreases in soil up to a certain period (Gulser et al., 2010 and Manivannan et al., 2009).

\section{Effect of green manures on coconut yield (nuts/palm/year)}

Application of green manuring practices significantly increased $(\mathrm{P}<0.05)$ nut yield over the control treatment. This increase in nut yield commenced from the fourth year after the first application of all treatments and the trend continued. The mean increment nut yield due to application of green manures $\left(\mathrm{T}_{1}\right.$ and $\left.\mathrm{T}_{2}\right)$ (Gliricidia and Tithonia) was $47 \%$ and $37 \%$ respectively when compared to the soils that did not receive green manures $\left(\mathrm{T}_{3}\right)$. This could be explained in terms of increased soil fertility due to application green manures for coconut palms.

It is interesting to note that there was no significant difference between the Gliricidia and Tithonia green manure application treatments $\left(\mathrm{T}_{1}\right.$ and $\mathrm{T}_{2}$ ) (Table, 9). Green manure like Gliricidia sepium helped the establishment of 2-month old poly bagged seedlings at $100 \%$ survival rate and the nut production increased by $42 \%$ while copra production by $45 \%$ at the end of the $5^{\text {th }}$ year (Mahindapala, 1989).However, there are reports of contrasting influences in field studies with long duration green manure applications. The influence of green manures on crop yields of maize and several other crops has been tested in the context of agroforestry systems. The results of green manure treatments and crops yields were diverse, and some studies illustrated more pronounced long-term beneficial influences (Sileshi and Mafongoya, 2006; Kimaro et al., 2007) or short-term influences (Sangakkara et al., 2004; Reddy et al., 2008 and Silva et al., 2008).

\section{Conclusion}

This study highlighted the importance of green manuring for coconut farming systems. It demonstrate the possibility of in situ cultivation of two green manure crops (Gliricidia sepium and Tithonia diversifolia ) in coconut plantation and their green biomass incorporation into the palm manure circle soil to increase organic matter content of the soil which ultimately adds soil macro and micronutrients besides improving soil physical and chemical properties. It stimulates soil biological activities which is necessary for soil health and fertility. It has positive effect on coconut yield and it is environment friendly and economical. It concluded that may be the use of in situ green manures along with chemical fertilizers, is essential to suppress any possible negative impact of fertilizers on the soil and to sustain soil productivity in coconut plantations. 


\section{References}

Ayeni, A. O., Lordbanjou, D. T., Majek, B. A., (1997). Tithoniadiversifolia (Mexican Sunflower) in south-western Nigeria: Occurrence and growth habit. Weed Res. (Oxford) 37, 443- 449.

Chirwa, T.S., Black, C.R., Ong, C.K. and Maghembe, J. (2006). Nitrogen dynamics in southern Malawi containing Gliricidiasepium, pigeon pea and maize, Agroforestry Systems 67: 93-106.

Doran, J.W., Fraser, D.G., Culik, M.N., Liebhardt, W.C. (1988). Influence of alternative and conventional agricultural management on soil microbial process and nitrogen availability. Am. J. Alternative Agric. 2, 99-106.

Egodawatta, W.C.P., Sangakkara, U.R., Stamp, P. (2012). Impact of Green Manure and Mineral Fertlizer Inputs on Soil Organic Matter and Crop Productivity in a Slopping Landscape of Sri Lanka. Field Crops Research, 129, pp. 21-27.

Eilitta, M., Mureithi, R., and Derpsch, P. (eds.) (2004). Green manure/cover crops systems of smallholder farmers. Kluwer Academic Publishers, London.

Eriksen, J. (2005). Gross sulphur mineralizationimmobilization turnover in soil amended with plant residues. Soil Biol. Biochem. 37, 2216-2224.

Fageria, N K. (2007). Green manuring in crop production. J Plant Nutrition 30: 691 719.

Follett, R.F., Paul, E.A. and Pruessner, E.G. (2007). Soil Carbon Dynamics during a Long Term Incubation Study Involving $13 \mathrm{C}$ and $14 \mathrm{C}$ Measurements. Soil Science, 172, 189-208.

Ganunga, R, Yerokun, O., Kumwenda, J. D. T., (1998). Tithoniadiversifolia: an organic source of nitrogen and phosphorus for maize in Malawi. In: Waddington SR et al. (ends) Soil Fertility Research for Maize-
Based Farming Systems in Malawi and Zimbabwe, pp. 191-194.

Gachengo, C.N., Palm, C.A., Jama, B., Othieno, C. (1999). Tithonia and Senna green manures and inorganic fertilizers as phosphorus sources for maize in western Kenya. Agroforestry Systems, 44: 21-36.

Generose, N., Cheryl, B., Rowland, J.B. and Paul, C.S. (1998). Soil phosphorus fractions and absorption as affected $b$ organic and inorganic sources. Plant and Soil, 1980: 159-168.

Hartemink, A. E. (2003): Soil fertility decline in the tropics - With case studies on plantations. $\mathrm{CAB}$ International, Wallingford, U.K.

George TS, Gregory PJ, Robinson JS, Buresh RJ, Jama BA (2001). Tithoniadiversifolia: variations in leaf nutrient concentration and implications for biomass transfer. Agroforest Syst 52:199-205.

Gulser, C., Demir, Z. and Serkan, I.C. (2010). Changes in Some Soil Properties at Different Incubation Periods after Tobacco Waste Application. Journal of Environmental Biology, 31, 671-674.

Hartemink, A. E. (2003). Soil fertility decline in the tropics - With case studies on plantations. $\mathrm{CAB}$ International, Wallingford, U.K.

Hsieh, H.C. and Hsieh, C.F. (1990). The use of organic matter in Crop Production, Food and Fertilizer Technology Centre Taipei, China, Extension Bulleting No. 315: 18.

Jama, B.A., Palm, C.A., Buresh, R.J., Niang, A.I., Gachengo, C., Nziguheba, G., Amadalo, B. (2000). Tithoniadiversifolia as a green manure for soil fertility improvement in Western Kenya: a review. Agroforestry Systems, 49: 201-202.

Jeyamala, M. and Soman P. (1999). Short term changes in soil fertility status in intensively managed Teak plantation. Indian Journal of Forestry, 22: 106-111 
JI, S. N. and Under, P. W. (2001): Soil water accumulation under different precipitation, potential evaporation and straw mulch conditions. Soil Science Society of America Journal 65, 442-448.

Joergensen, R.G. (2002). Challenges to organic farming and sustainable land use in the tropics and subtropics. J. Agric. Tropics and Subtropics 103: $105-105$.

Kimaro, A.A., Timmer, V.R. and Mugasha, A.G. (2007). Nutrient use efficiency and biomass production of tree species for rotational woodlot systems in semi-arid Morogoro, Tanzania. Agroforestry Systems 71: 175-184.

Kuchenbuch, R. O. and Ingram, K. T. (2004). Effects of soil bulk density on seminal and lateral roots of young maize plants (Zea mays L.). Journal of Plant Nutrition and Soil Science, 167, 229-235.

Mahindapala, R. (1989). Coconut Research Institute of Sri Lanka Report. CRB, Sri Lanka.

Mapa, R.B., Dassanayake, A.R. and Nayakekorale, H.B. (2005). Soils of the Intermediate zone of Sri Lanka: morphology, characterization and classification. Soil Science Society of Sri Lanka, Peradeniya, Sri Lanka.

Manivannan, S., Balamurugan, M., Parthasarathi, K., Gunasekaran, G. and Ranganathan, L.S. (2009). Effect of Vermicompost on Soil Fertility and Crop Productivity-Beans (Phaseolus vulgaris). Journal of Environmental Biology, 30, 275-281

Nagarajah, S. and Amarasiri, S.L. (1977). Use of organic materials as fertilizers for lowland rice in Sri Lanka. Soil organic matter studies. International Atomic Energy Agency, Vienna, Austria, 97-104.

Niang, A., Amadalo, B., Gathumbi, S. and Obonyo, C.O. (1996). Maize yield response to green manure application from selected shrubs and tree species in Western Kenya: a preliminary assessment. In:
Mugah J O (ed) Proceedings of the First Kenya Agroforestry Conference on People and Institutional Participation in Agroforestry for Sustainable Development, pp. 350-358.

Nosengo, N. (2003). Fertilized to death. Nature, 425, pp. 894-895.

Olabode, O.S., Ogunyemi, S., Akanbi, W.B., Adesina, G.O. and Babajide, P.A. (2007). Evaluation of Tithoniadiversifolia (Hemsl.) A Gray for soil improvement. World Journal of Agricultural Sciences 3 (4): 503-507.

Okogun, J.A., Sanginga, N. and Mulongoy, K. (2000). Nitrogen contribution of five leguminous trees and shrubs to alley cropped maize in Ibadan, Nigeria. Agroforestry Systems 50-2: 123-136.

Palm, C.A, Gachengo, C.N., Delve, R.J., Cadish, G, Giller, K.E. (2001). Organic inputs for soil fertility management in tropical agroecosystems: application of an organic resource base. Agric. Ecosys. Env. 83: $27-$ 42.

Reddy, K.S., Mohanty, M. and Rao, D.L.N. (2008). Nitrogen Mineralization in a Vertisol from organic manures, green manures and crop residues in relation to their quality. Agrochimica 52-6: 377-388.

Sangakkara, U.R. (1989). The role of leguminous alley crops in the nitrogen nutrition of selected annual crops in smallholder farming systems of Sri Lanka. Van der Heide, j. (Eds.) Nutrient management for food crop production in tropical farming systems; symposium, Malang, Indonesia, October 19-24, 1987. V+394p. Institute for soil fertility: Haren, Netherlands; Universitas Brawijaya: Malang, Indonesia: 271-278.

Sangakkara, U.R., Liedgens, M. and Soldati, A. (2004). Root and shoot growth of maize (Zea mays) as affected by incorporation of Crotalaria juncea and Tithoniadiversifolia as green manures. Journal of Agronomy and Crop Science 190: 339-346. 
[SAS] Statistical Analysis Systems, (1999). SAS 1, STAT Users Guide, Release, 7.00 Cary, NC: Statistical Analysis Systems Institute, 1028.

Schjonning, P., Elmholt, S. and Christensen, B. (eds.) (2004): Soil quality management Concepts and terms. In: Managing soil quality: Challenges in modern Agriculture. CABI, Wallingford, U.K, 1-16.

Sileshi, G. and Mafongoya, P.L. (2006). Longterm effects of improved legume fallows on soil invertebrate macrofauna and maize yield in eastern Zambia. Agriculture Ecosystem and Environment 115: 69-78.

Silva, G.T.A., Matos, L.V. and Nobrega, P.D. (2008). Chemical composition and decomposition rate of plants used as green manure. Scientia Agricola 65: 298-305.

Six, J., Conant, R.T., Paul, E.A. and Paustian, K. (2002). Stabilization mechanisms of soil organic matter: implications for $\mathrm{C}$ saturation of soils. Plant and Soil, 241, $155-176$.

Stokdale, E. A., Lampkin, N. H., Hovi, M., Keating, R., Lennartsson, E. K. M., Macdonald, W., (2000). Agronomic and environmental implications of organic farming systems. Advances in Agronomy, 70, pp. 261-327.

Zingore, S., Mafongoya, P., Nyamugafata, P. and Giller, K. E. (2003). Nitrogen mineralization and maize yields following application of tree prunings to a sandy soil in Zimbabwe. Agroforesty Systems 57, 199-211. 